\title{
Challenges Faced by the Nursing Team in the Care of Burned Victim: Literature Review
}

Izabel Fernanda Xavier Silva', Larissa Lima Moulin', Sara Porfírio de Oliveira', Rodrigo Assis Neves Dantas², Maria do Carmo de Oliveira Ribeiro ${ }^{3}$, Daniele Vieira Dantas ${ }^{2}$, Isabelle Cristina Braga Coutinho Cunha4, Maria Solange Moreira de Lima ${ }^{5}$, Ana Elza Oliveira de Mendonça ${ }^{6}$, Ellen de Fátima Lima Vasconcelos ${ }^{1}$, Rayane Araújo do Nascimento ${ }^{1}$, Glória Catarina Beserra Rodriguez' Sabrina Daiane Gurgel Sarmento ${ }^{1}$, Roberta de Lima Cavalcanti ${ }^{1}$, José Joandson de Souza dos Santos ${ }^{1}$, Izabelle Cristine Tarquinio de Carvalho ${ }^{1}$, Izabelle Bezerra Costa ${ }^{1}$, Kezauyn Miranda Aiquoc ${ }^{1}$, Millâny Kivia Pereira Soares ${ }^{1}$, Karen Rayara Bezerra Lima1, Tiago Alves de Brito

\section{Abstract}

Introduction: Burned patient care needs the involvement of a multidisciplinary team, and nursing is a key role in this care since it is the professional category in constant contact with the patient and his family. However, nursing faces challenges on the care for burned victims and their constant exposure to suffering and pain.

Objective: To identify the challenges of the nursing staff in the care of burned patients according to scientific literature.

Method: This is a literature research, conducted between April and May/2016 in the Latin American databases and Caribbean Health Sciences (LILACS), the Nursing Database (BDENF) and the Medical Literature Analysis and Retrieval System online (MEDLINE), available on the Virtual Health Library (VHL), and Google Scholar, using the keywords: "Nursing" and "Burn Units" with Boolean operator AND. The keywords crossing resulted in 282 scientific publications, of which 14 articles were selected addressing the topic, through the inclusion criteria: full-text availability, published between 2011 to May/2016, in Portuguese and English. The articles in duplicate (published in more than one selected database) were excluded.
1 Nursing student at the Federal University of Rio Grande do Norte/ UFRN. Member of the Studies and Research in Emergency, Urgency and Intensive Care (NEPET)/CNPq. Natal/ RN, Brazil.

2 Nurse. Associate Professor of the Department of Nursing of the Federal University of Rio Grande do Norte/ UFRN. Leader of the Research Group of Studies and Research in Emergency, Urgency and Intensive Care (NEPET)/ CNPq. Natal/RN, Brazil.

3 Nurse. Associate Professor of the Department of Nursing of the Federal University of Sergipe /UFS. Leader of the Research Group ALIVIEADOR/CNPq. Aracaju/SE, Brazil.

4 Municipal Nurse of Natal, Rio Grande do Norte. Professor and Coordinator of the Post-Graduate Health Area at Estácio Ponta Negra/Maurício de Nassau. Specialist in Parasitology, Family Health, Urgency and Emergency, Obstetric Nurse and Auditory Health System.

5 Nurse. Cardiology resident at University Hospital Onofre Lopes/Federal University of Rio Grande do Norte.

6 Nurse. Associate Professor of the Department of Nursing of the Federal University of Rio Grande do Norte/ UFRN.

\section{Contact information:}

Izabel Fernanda Xavier Silva.

झ izabelfernanda11@hotmail.com 
Results: The following challenges were observed in the nursing staff: assistance to the burned patient and guided planning in the Nursing Process (NP), related to the appropriate hemodynamic monitoring, control of infectious processes and pain; emotional professional support that the victims watch sensitized, exposed to pain, suffering, and guilt, often involved in the professional-patient-family cycle, arousing mixed feelings of grief and gratitude.

Conclusions: It is necessary to understand these challenges and provide continuing education and inputs that support assistance guided to the nursing process. Moreover, it is essential to promote emotional support through health institution, encouraging professionals to report their anguish and difficulties to cope with the stressful and limiting factors in the work process involving the care of burned victims.

\section{Keywords}

Nursing; Burn Units; Nursing Care.

\section{Introduction}

Burns are traumatic injuries caused by thermal, chemical, electrical, biological or radioactive agents. They act in the human body tissues lining (epithelial, connective, muscle and nerve), causing the partial or full destruction of the skin and its appendages, reaching deeper layers of subcutaneous tissue, muscles, tendons, and bones. [1]

It is a public health problem, although it is not part of prevention campaigns provided by the state or federal levels to guide the population in accidents involving fire or those predictable accidents. In Brazil, it represents a million accidents per year and 2,500 people direct or indirectly die because of the injuries. The main victims are usually children under 15, young male adults and the elderly. According to the World Health Organization (WHO), about 300,000 people die annually worldwide because of burns, where the women, young and disadvantaged economically people are the main affected. $[2,3,4]$
These injuries are measured in degrees, according to the depth of tissue trauma, that is according to the skin layers impairment. In the 1st degree burn, the impairment is limited to the epidermis, in the 2nd degree, the epidermis is involved as well as part of the dermis and in the 3rd degree, the burns destroy the epidermis and dermis and may reach the subcutaneous tissue, tendons, ligaments, muscles, and bones. In the 4th degree, the burns affect all layers of the skin, underlying fat, muscle, bone, and internal organs. [1, 5, 6]

There is also the evaluation of the burn's extension. The size of the affected body area can be done through the Rule of Nine with nine points representing the parts of the body, and the Lund-Browder Table, using a proportion of the body about age and a standardized value, contributing to an adequate fluid replacement. The injuries can be called small, medium and large according to the extent of the injury and may be small with a length of $10 \%$ $-20 \%$, medium and large with over $20 \%$ of the affected body area. [1] 
The burned patient care needs the involvement of a multidisciplinary team including nurses, nursing technicians, doctors, physiotherapists, nutritionists, psychologists, speech therapists, dentists, and social workers. Nursing plays a fundamental role in this care, being the professional category in constant contact with the patient and his family, providing physical and emotional support. [7]

However, nurses and nursing technicians face challenges in the care for burned victims due to the sudden hospitalization of the patient, affecting their routine habits, independence, and image, making the professional work an environment with pain, suffering, depression and uncertainty about their recovery. This setting affects the psychologically and physically of these professionals since the workload tends to stress the team.

Nevertheless, improved discharge and return visits are aspects contributing to the professional remaining in the sector. Although the nursing witnesses and provides care in pain and suffering moments, it also acts in the continuous emotional rehabilitation of the patient, providing measures to ease painful procedures or just showing interest in patients' improvement. $[5,7]$

Based on this, this work is justified by the need to understand the difficulties that nurses and nursing technicians face when taking care of the burned patients, adults or children, seeking to identify factors that burden the professional in the exercise of care. Thus, it contributes to knowing the professionals profile and the dynamics of their work environment, allowing the reader to know the team is providing care for burned victims.

In this context, the question is: what are the challenges faced by the nursing team in the care of burned patients? To answer this question, the objective of this paper is to identify the challenges of nursing staff in the care of burned patients according to the scientific literature.

\section{Method}

This is a literature research of qualitative approach about the challenges faced by the nursing team in the care of burned patients.

A research was carried out to identify the necessary publications to the study in April and May/2016 in the databases Latin American and Caribbean Health Sciences (LILACS), Nursing Database (BDENF) and Medical Literature Analysis and Retrieval System Online (MEDLINE), all available in the Virtual Health Library (VHL), and Google Scholar, using the keywords: "Nursing" and "Burn Units" with Boolean operator AND.

The crossing keywords resulted in 282 scientific publications with 14 articles selected addressing the topic of the study, through the inclusion criteria: full-text availability, published between 2011 to May/2016, in Portuguese and English. The articles duplicated (published in more than one selected database) were excluded.

For the organization of the publications, they were cataloged in 11 publications according to the title, author, year, database, type of study, observed challenges and link (for quick access to the file). This data compression facilitated the visualization of the studies. The articles were analyzed using critical-reflective reading and then, the results were elaborated as: "Burned patient care."

\section{Results}

As an essential part of the patient treatment, care is a way to promote prevention and recovery, being a competence of the health areas, especially nursing. When this care is related to the provision of assistance to the burned victims, the care act leads the professionals to experience a diverse everyday life, with technical and scientific knowledge required, as well as emotional preparation, since these workers perform complex and repetitive care and deal with the pain and the process of death and dying. $[2,3]$ 
After reading and a detailed analysis of the scientific papers, it was observed that the challenges are linked to two difficulties: burned patient care, performing infection control interventions, planning and hemodynamic monitoring; and emotional support to the nursing staff when the professional has to deal with the double day of giving and receiving help in the psychological context.

\section{Burned Patient Care}

Nursing has enjoyed progress in the burned people treatment, and it has been increasingly necessary to expand scientific knowledge for the professional. Knowing how to identify causes, classify its depth, verify the extent and location of the injury and necessary actions are the basic requirements to promote effective interventions. However, there are still challenges to be overcome, such as the appropriate care planning, working in infection control and the burned patient complex monitoring. [8]

Patients who have suffered some burn have physical and emotional commitment damage. Nursing care is needed in situations like this, where treatment must be immediate and effective. However, besides it is a technical knowledge care, it is also established by the availability of professionals for clarifying doubts and encouraging on fears and anxieties. [2]

When planning, the nursing staff must be attentive to the level of commitment and the nurses should apply the Systematization of Nursing Assistance (SNA), performing data collection, identifying the possible causes of the problem and signs and symptoms that define nursing diagnoses, to then planning the care establishing priorities in the implementation according to the clinical findings and information collected. Daily changes of these priorities should be made according to the patient, and it is vital that the nursing staff is attentive to minor changes in the parameters and can establish a relationship of trust with the patient, in an attempt to create a bond and provide more effective care. [2]
The observation of these aspects becomes a challenge for the team since the care maintenance is linked to a plan, being necessary critical thinking and good interaction with the patient who may have some obstacles defined by the nursing diagnoses such as Impaired Verbal Communication; Defensive Coping and Impaired Resilience.

\section{Infection control}

The infections are one of the most serious complications of burned patients since the injury conditions can predispose to bacterial growth. In the context of hospital infections, the burned patient injury infection is the most prevalent and involves rigorous prevention by professionals, visitors, facilities, and equipment. $[9,10]$

Its prevention begins with sanitizing hands before and after contact with the patient and the use of Personal Protective Equipment (PPE). Then, preventive measures are followed to procedures performed in the bath as the rapid removal of exudate and necrotic tissue, preventing the proliferation of microorganisms. Sterile technique and tools shall be used to avoid cross-contamination as well as the care when changing the dressing and the venous catheter.

Furthermore, the balneotherapy, debridement, and topical therapy considerably reduce infections and, consequently, reduce the mortality of patients with infection. It is noticeable that dealing with this preventive picture critical thinking through the use of SNA is required, enabling to understand and identify potential infectious processes, thus demonstrating the applicability of the Nursing Process in assisting burned patients. Based on this, it is necessary enough professionals to assist the patient without having excessive workload fully, and the care is provided in a comprehensive and effective way. $[9,10]$ 


\section{Pain}

Pain in burned victims should be observed at the first evaluation. Considered as the fifth vital sign, pain needs to receive attention and be recorded, registering and controlling it. Thus, it is necessary to educate the staff to deal with the pain and how to manage it. The effectiveness of treatment can be measured by pain when there is a reliable information collected. For this, a good relationship between patient and professional is needed both having an effective dialogue. However, the great challenge of the nursing staff is to deal with the pain. Due to academic failure preparing professionals who can work with the pain, there is a lack of evaluative, individualized and biological knowledge beyond the technical capacity of care. These and other factors are crucial for a consistent evaluation of pain reported by the patient. [11]

\section{Burned Patient complex monitoring}

The burned patient is usually hemodynamically unstable, with the loss of capillary integrity, hypovolemia, and inadequate oxygen supply to the effective maintenance of cardiac output, essential to have continuous hemodynamic monitoring so the clinical picture can be monitored, with systemized care and optimized treatment. However, the nursing team often faces challenges regarding the measurement of vital signs, breathing pattern, hemoglobin saturation, urine output, body temperature, monitoring of central venous pressure and pulmonary artery pressures, evaluation of the lactate, cardiac output measurement, electrocardiogram and perform serial testing because there is no availability of materials or skilled professionals. [12]

The monitoring process become more complex with the patient's physical condition, preventing to verify the oxygen saturation with pulse oximetry due to edema, the setting of cardiac monitoring electrodes and the use of sphygmomanometer due to skin integrity of the injury, or other more invasive monitoring, such as pulmonary artery catheter, central venous pressure (CVP) and mean arterial pressure (MAP). Obstacles like these make the process look even more complex, requiring a good articulation of the whole team to circumvent the challenges and to provide appropriate care. [12]

\section{Emotional Support To The Nursing Staff}

In many situations, the patient who suffered some trauma becomes a difficult and complex patient for care and the nursing care provides physical and emotional support, considered a challenging task. The professionals have difficulties to be involved with the situation, facing daily mixed feelings of grief and gratitude. [3]

Suffering is evidenced when the professionals are placed in the patient's shoes, or they imagine their families in the same situation, when they feel powerless to help, especially in the management of pain, which is a nursing activity, or when caring for a suicide patient, awakening different emotions in the professional observing that the patient wanted to take his life. [11, 13, 14]

However, according to the literature, the situation that generates more suffering is the care for the child burned victim. Observing the patient suffering, the professional imagine their children or relatives in the same situation. In some cases, this thought makes a more humanized care. There are still cases where the child is feeling guilty, sorry for his disobedience, being even a more distressing work, because besides facing the pain, the patient feels guilty. In other cases, the team tends to blame the parents for the problem, and that feeling interferes with the care provided and conviviality. $[11,13,14]$

On the other hand, gratitude appears most often in hospital moments, reflecting the success of the team, but also as a challenge to work in a burn unit seeking rehabilitation. Receiving the patient's visits after discharge is seen as a rewarding time. However, it was noted that following the report of gratification, it was always evident that the work 
is exhausting and challenging, which highlights the need for emotional support to the nursing staff. $[3,14]$

\section{Discussion}

It is known that the nursing professionals are the closest professionals to the patient, providing ongoing support and being daily exposed to stressful and challenging situations. This is well evidenced in the care of burned victims and the patient monitored during the rehabilitation process, being an arduous task that involves a lot of physical and emotional exhaustion.

The professional is prepared to provide the technical care, and when starting it, he faces challenges in this area, since it is a specific and careful care, and it requires professional theoretical domain and grounding on SNA to provide a structured service. When dealing with the burned patients, the challenging task is to maintain physiological stabilization of the victim. However, limiting factors such as not having a place on the skin for placing the monitoring equipment or unable to control the infection and the body temperature makes the professional victim of his work, exposed to situations that the immediate need of the customers is damaged due to these limitations. $[9,12]$

Moreover, the emotional suffering becomes present in the work routine. Dealing with adults and children who suffer, take care to insert them back into the society without so many traumas that make them suffer prejudice, imagining their families in the same situation or having a place on the skin to place monitoring equipment are limiting factors at work and generate a sense of emotional exhaustion, making the professional victim of his work.

This daily confrontation shows that nursing professionals need emotional support who can share their anxieties and frustrations to be heard, understood and supported. Working emotional control is a way to improve the work of the nursing staff, making it more human and prone to understand the cultural and family context of each patient, providing an individualized and effective care focused on the application of SNA so that care measures are comprehensive and effective. $[2,3,14]$

\section{Conclusion}

The results show that the work of the nursing staff with burned victims is challenging both for the technical issue with a healthcare planning guided in the $N P$, involving proper monitoring and tight control of infectious processes and pain, as the emotional issue, leading to sensitized and exposed victims pain, suffering, and guilty. Understanding these difficulties, a new way for proposals to support these professionals is open, seeking to understand the context of the operation and the type of care provided, always showing that the physical and especially mental health of workers should be observed and support for the health institutions. It is necessary to follow these professionals and encourage them to share the feelings experienced so that the work becomes more fluid and less stressful.

\section{References}

1. Hargreaves LHH, Dantas RAN. Atendimento Pré-Hospitalar e Múltiplas Vítimas/Catástrofes. 1ed. Rio de Janeiro: Águia Dourada; 2016.

2. Oliveira TS, Moreira KFA, Gonçalves TA. Assistência de enfermagem com pacientes queimados. Rev Bras Queimaduras [Internet], 2012 May [cited 2016 may 10] 11(1): 31-7. Available from: http://www.rbqueimaduras.com.br/detalhe artigo. asp?id=97.

3. Duarte MLC, Lemos L, Zanini LNN, Wagnes ZI. Percepções da equipe de enfermagem sobre seu trabalho em uma unidade de queimados. Rev Gaúcha Enferm [Internet], Porto Alegre, 2012 May. [cited 2016 may 10] 33(1): 77-84. Available from: http://www.scielo.br/scielo.php?script=sci_arttext\&pid $=$ S1983-14472012000100011. 
4. Henrique $D M$, Silva $L D$, Costa $A C R$, Rezende $P M B$, Santos $e$ Santos JÁ, Menezes MM, Maurer TC. Controle de infecção no centro de tratamento de queimados:revisão de literatura. Rev Bras Queimaduras [Internet], 2013 Nov. [cited 2016 may 10] 12(4):230-4. Available from: http://rbqueimaduras.org.br/ detalhe artigo. asp?id=181.

5. Lima OBA, Arruda AJCG, Carvalho GDA, Melo VC, Silva AF. A enfermagem e o cuidado à vítima de queimaduras: Revisão Integrativa. Rev enferm UFPE on line [Internet], Recife, 2013 July [cited 2016 may 10] 7(esp): 4944-50. Available from: http://www.rbqueimaduras.com.br/detalhe artigo.asp?id=97.

6. Montes SF, Barbosa MH, Sousa Neto AL de. Aspectos clínicos e epidemiológicos de pacientes queimados internados em um Hospital de Ensino. Rev Esc Enferm Usp [Internet], São Paulo, 2011 Recife, 2013 July [cited 2016 may 10] 45(2): 69-73. Available from: http://www.scielo.br/scielo.php?script=sci artt ext\&pid=S0080-62342011000200010.

7. Silva RMA, Castilhos APL. A identificação de diagnósticos de enfermagem em paciente considerado grande queimado: um facilitador para implementação das ações de enfermagem. Rev Bras Queimaduras [Internet], 2010 Recife, 2013 July [cited 2016 may 10] 9(2): 60 - 5. Available from: http://www.rbqueimaduras. com.br/detalhe_artigo.asp?id=36.

8. Culleiton AL, Simko LM. Caring for patients with burn injuries. Nursing [Internet], 2013 Aug. [cited 2016 may 10] 43(2):26-34. Available from: http://pesquisa.bvsalud.org/portal/resource/pt/ mdl-23793299.

9. Chaves SCS. Ações da enfermagem para reduzir os riscos de infecção em grande queimado no CTI. Rev. Bras. Queimaduras [Internet], 2013 July [cited 2016 may 10] 12(3): 140-44. Available from: http://pesquisa.bvsalud.org/portal/resource/pt/lil-752795.

10. Camuci MB, Martins JT, Cardeli AAM, Robazzi MLdoCC. Nursing Activities Score: carga de trabalho de enfermagem em Unidade de Terapia Intensiva de queimados. Rev. Latino-am. Enfermagem [Internet], 2014 Mar. [cited 2016 may 10] 22(2):325-31. Available from: http://pesquisa.bvsalud.org/portal/resource/pt/lil-710309.

11. Silva BA, Ribeiro FA. Participação da equipe de enfermagem na assistência à dor do paciente queimado. Rev Dor [Internet], São Paulo, 2011 Oct. [cited 2016 may 10] 12(4):342-8. Available from: http://pesquisa.bvsalud.org/portal/resource/pt/lil-609263

12. Canela AF, Sória DAC, Barros FE, Melos ROL, Castro RC. Monitorização do paciente grande queimado e as implicações na assistência de enfermagem: relato de experiência. Rev. Bras. Queimaduras [Internet], 2011 Oct. [cited 2016 may 10] 10(4):13337. Available from: http://pesquisa.bvsalud.org/portal/resource/ pt/lil-750424.
13. Soares NTI, Tacla MTGM. Vivência da equipe de enfermagem frente à hospitalização da criança queimada. Invest Educ Enferm [Internet], 2014 Jan. [cited 2016 may 10] 32(1): 49-59. Available from: http://pesquisa.bvsalud.org/portal/resource/pt/lil-715240.

14. Martins JT, Bobroff MCC, Ribeiro RP, Soares MH, Robazzi MLCC, Marziale MP. Sentimentos vivenciados pela equipe de enfermagem de um centro de tratamento de queimados. Esc. Anna Nery Rev. Enferm [Internet], 2014 July [cited 2016 may 10] 18(3):522-26. Available from: http://pesquisa.bvsalud.org/ portal/resource/pt/lil-719360.
Publish in International Archives of Medicine

International Archives of Medicine is an open access journal publishing articles encompassing all aspects of medical science and clinical practice. IAM is considered a megajournal with independent sections on all areas of medicine. IAM is a really international journal with authors and board members from all around the world. The journal is widely indexed and classified Q2 in category Medicine. 